\title{
Contemporary State of Research, Goals and Preliminary Conclusions Regarding the Architecture of Medieval Crimea*
}

\author{
Armen Kazaryan \\ State Institute for Art Studies \\ Moscow, Russia \\ armenkazaryan@yahoo.com
}

\begin{abstract}
This paper looks into the present-day stage of studies on Crimean Medieval architecture, focusing on their specific features and defining the objects for future work, which is expected to place them within a broader context, in close connection with other historical research dedicated to Mediterranean, Eastern European and Black Sea region art. The limited scope of themes covered by previous works on the subject, which were conducted mainly by archaeologists, were not closely connected with those questions that are usually put forward and answered by art historians, including specialists on architecture. Presently, in studying the latter in Crimea, it is essentially important to introduce a specific approach used by art historians, moving away from describing exclusively construction technique and typology. Outlining the architectural image of the edifices may certainly help us clarify the process of integration with regard to national traditions of Greeks, Armenians, Genoeses, Karaites, people of the Golden Horde and Tartars, who succeeded them, i.e. all those who had lived on the peninsula for centuries. They created numerous buildings that can be compared in the light of their construction methods, architectural details and ornamentation. A look at Crimean edifices will appear especially fruitful, if we turn to various approaches based on critical analysis in studying every construction against the background of a broader context, involving the development of Medieval architecture.
\end{abstract}

Keywords-medieval architecture; archeology; Crimea; integration of architectural traditions

\section{INTRODUCTION}

Crimea, doubtless, is one of the singularly impressive, diverse and, consequently, most interesting regions in terms of art history and monumental architecture. It was a place, where, owing to wars and waves of migration, different ethnic entities occasionally replaced one another. Thus Taurica became a place where the most varied architectural ideas were implemented. Inhabitants of Crimea raised towns and constructions, which, seen as a single entity, at first

*The study done due to the support of the Russian Foundation for Basic Researches (RFBR), no. 17-04-00643 “Armenian architectural and artistic heritage of the Southern Russia: Churches and monasteries, their liturgical things and manuscripts of the 17th -19th centuries (on the materials of Moscow, Rostov-on-Don, Astrakhan and Crimea collections). glance may appear as a motley mosaic.

This work aims at attempting to analyze the present-day situation in historical research devoted to Medieval Crimean architecture, to describe its strong and weak points and to outline new objectives. Preliminary results of this process are also be specified, which demonstrate the potential advantages of focusing on the architectural heritage of this region by directly using the methods of architectural analysis.

\section{STAGES AND SPECIFIC FEATURES OF STUdIES \\ DEDICATED TO MEDIEVAL CRIMEAN ARCHITECTURE}

Since ancient times Greek settlers, who began to live on the coast, developed here the traditions of classical antiquity, contrasting with the culture of the steppe nomads of the interior lands of the peninsula, the latter, however, experiencing some influence of classical forms. Greeks and Romans would still be present here in the future, and in early Christian and early Byzantine times they were raising new towns and impressive churches. A radical change took place in the Middle Ages, especially between the 13th and the first half of the 15th centuries, when many Genoeses, Armenians and Tartars, who had moved here in large numbers, were now conducting important construction work. The flourishing of architecture was not only accompanied by close contacts, but also by opposition between different political entities, as well as by competition, involving the interests of major religions. Republic of Genoa, Principality of Theodoro, the Golden Horde, the Crimean Khanate, and the Ottoman Empire, sometimes consecutive and sometimes parallel in time, controlled the Crimean territory, creating a basis for the development of international trade. The peninsula became an excellent ground for combining European and Asian civilizations. Located in towns and fortresses, crowning mountain ridges or hiding in the hollows of this expressive landscape, the edifices raised by local Greeks, Italians, Armenians, Tartars, Karaites represent a unique example of combining architectural heritage, a large part of which are monumental structures.

Crimea became a place of pilgrimage for those interested in antiquities since the second half of the 18th century. Descriptions, drawings, first measurements and 
archaeological excavations formed the initial basis of research, and many documents of the period are still used in modern works.

In the late 19th and early 20th centuries, such figures as engineer K.E. Dumberg, who worked on the ruins of ancient Panticapaeum; A.L. Bertier-Delagarde - on the site of Tauric Chersonesos; archaeologist N.I. Repnikov - in Eski-kermen and Chersonesos; as well as digs actively conducted since the mid-20th century by Soviet specialists introduced to the public a large number of architectural monuments. Even at the initial period of archaeological research much attention was given to the Medieval constructions of the peninsula, particularly to churches [1]. They were not studied systematically, but the general notion of the periods connected with ecclesiastic constructions was formed early, the number of monuments that attracted attention continually increased, while new discoveries in connection with churches lying deep within the occupation layer still continue today [2] [3] [4]. Moslem architecture in Crimea was not studied as actively, a situation that changed in recent decades.

Nevertheless, we still do not have a general work dedicated to Medieval Crimean architecture. A single historical index of architectural monuments and monumental art is also absent. This is why three years ago some scholars came up with the idea of creating a catalogue of Crimean monuments. Initially the project was supposed to include (which is unlikely to be carried out under present political circumstances) constructions belonging to all epochs, from antiquity to the first half of the 20th century.

As the first volume began to take shape some gaps became apparent, including not only a large number of constructions that had not been analyzed, but also the specific features of research conducted in Crimea, the majority of which accompanied and summarized archaeological studies. In the case of Crimea, the typical trait is priority of archaeology over art history, part of which is the history of architecture.

It seems that it was archaeology being everywhere and primarily interested in antiquities, while focusing its attention on establishing the layouts of settlements, studying the foundations or the remains of edifices and occupation layers around them. The buildings themselves, their architectural details were perceived as one of the numerous artifacts of material culture, with primary importance being given to those objects, which allow us to accurately date occupation layers, such as coins or epigraphic inscriptions. The history of architecture is based on archaeological data, but its goals are substantially different, being in many ways similar to those of art studies. The former is interested in issues of archaeological stratigraphy to the extent of finding out and dating the various layers of early structures. It also uses the acquired facts in order to reconstruct an edifice that may lie in ruins. Architectural analysis, nonetheless, has its independent function, that includes different aspects, demanding an approach to the monument within the context of evolution of construction and of culture as a whole. This analysis, in its advanced form, is based on the methods of art history, as long as we consider architecture as a form of art.
However, it is this latter approach, involving the methods of art history, that we find lacking with regard to Crimea during more than a hundred years of scientific research. It would be enough to remind one of the character of the work, conducted by the famous archaeologist A. L. Yakobson, which covered a very wide range of early Christian, Byzantine and Armenian churches on the peninsula. We may perceive here the limitations of these publications that do not go beyond the analysis of the historical context connected with the appearance of the structures, and beyond the construction technique and typology of the edifices [5]. The same attitude dominated the works describing the architecture of specific regions or that of particular ethnic groups inhabiting Taurica, such as papers of $\mathrm{O}$. Kh. Khalpakhchian devoted to the Armenian architectural heritage of Crimea [6] [7]. This methodology in its advanced form is present in the works of V.P. Kirilko, dedicated to the Moslem constructions of the Golden Horde and Crimean Khans, which contain detailed graphic layouts, information on the various periods of construction strata and reconstruction of the buildings [8] [9]. In her relatively recently published monograph on the architecture of the Golden Horde, E. D. Zilivinskaya pays adequate attention to Crimean monuments. But this author omits any discussions on serious issues that may arise, and does not in any way treat the problem of architectural development in Crimea itself, even though we can read short descriptions of not only Moslem, but also of Christian structures belonging to three different confessions [10]. It appears that the only effort to study an early building from the point of view of an art historian is the work by A. I. Komech, where he writes about the Church of St. John the Baptist in Kerch [11]. Another singular effort was made by V.A. Sidorenko, as the author studied architectural styles [12].

Thus in the majority of cases dealing with Crimean antiquities scholars do not discuss in any way the problems that go beyond purely historical or archaeological subjects. Incidentally, such important phenomena for Medieval architecture and urban structure as walls, towers and gates, which are richly represented in such cities as Feodosia and Sudak, never became an object for specifically architectural analysis. Some detailed research, against a broad historical background, of the Genoese Gazara, the Principality of Theodoro, the cave towns of Taurica, conducted by S. G. Bocharov V. L. Myts, Y. M. Mogarichev, E. A. Aybabina, V.P. Kirilko and others give us a lengthy description of the archaeology of settlements and separate fortifications, but have no intention of carrying out a comprehensive architectural analysis of the material [12] [13] [14] [15] [16] [17]. This kind of research, doubtless, should be continued further, but at the same time we have a right to expect works in the field of the history of architecture and art studies. Such works that already exist with regard to the Medieval heritage of other regions of the Mediterranean, Black Sea and Eastern Europe. 


\section{SOME PRELIMINARY RESUlts OF NEW RESEARCH ON CRIMEAN ARCHITECTURE}

Work on the first book, a study and catalogue of Crimean architecture - "Monuments of the Architecture of Bosporus and Eastern Crimea in the Epochs of Antiquity and Middle Ages", resulted in a draft version completed in 2016 (principal authors: A. Y. Kazarian, O. V. Bayeva, V. P. Kirilko, T. E. Sargsian, V. P. Tolstikov, L. G. Khrushkova). It put forward and partly succeeded in solving some of the problems, allowing us to come up with an overview of the evolution of monumental architecture and to define its place within the architectural context of certain vast territories: from Greece to the Middle East and from Egypt to Galicia. The section, devoted to the Middle Ages, turned out to be especially abundant in terms of material and possibilities of conducting an architectural analysis.

Our principal object was to outline the national characteristics of the architecture, created by Greeks, Italians, Armenians, Tartars, as well as to describe its specific features as they were interpreted in Crimean lands. It were not just issues connected with national traditions, but also with the conscience of belonging to a particular religious group, which determined the choice of the builders of religious and memorial constructions, who selected a certain typology and, largely, the iconography of the architecture of the erected buildings.

Looking at Crimean edifices, we may note that both the concepts of a hall and a domed church plan were embodied among Greeks, Italians and Armenians. But a closer look at this particular type of constructions clearly shows us the adherence of, for instance, the Greek and Armenian patrons and architects, responsible for creating domed churches, to that specific variant of the universal cross-domed model, which centuries ago had been worked out in their "historical" homeland or "metropolitan country". Connections between the "colonies" and the "mother countries", reflected in construction, could be based on actual ties or on historical memory. This is evident in the case of the Church of the Beheading of St. John the Baptist in Kerch and of another church, dedicated to the same prophet, in the Karantin quarter of Feodosia. The world in the Middle Ages was much more close and mobile than we sometimes imagine. Neither the first, nor the second of these constructions had a prototype on the lands of the peninsula (judging by extant edifices). For the first of them there was chosen a Byzantine model supported by four columns, for the second - a typically Armenian design of a hall church, its variant being characteristic of the high Middle Ages. However, as the chosen scheme appeared in stone, both constructions turned out to be highly individual, not resembling the dozens of uniform models that existed in other parts of the Greek and Armenian worlds. Studying both of these and other churches helps us discover in them certain traits, which were taken from neighboring traditions, transformed and combined with traditional styles. In the case of the Kerch church one can see over marble columns cross-shaped pillars, unusual for Byzantine architecture, but widespread in Armenian lands. At the same time, the typical Byzantine masonry of stone and plinthiform brick forming the façade of this church gave rise to certain conjectures that the idea of striped covering was inspired by Italian architecture [11]. In the case of the above-mentioned church in Feodosia Armenian masters turn to some carving motives, which have been known in Armenia since the 11th century, and in the 14th-15th centuries became widespread in Christian and Moslem edifices in Crimea (these are associated by scholars with Seljuk décor). We cannot exclude the possibility that the church was founded as early as the 13th century, and was reconstructed later, in 1348. At this time the interior of the building was embellished with reliefs that reflect the simultaneously existing architectural tradition of the Armenian province Syunik, while stylistically they seem close to the proto-Renaissance sculpture of Northern Italy [18].

In order to understand the mutual influence of traditions it is also interesting to compare architectural details and separate forms. Suggestive are the portals of Armenian and Tartarian buildings, framed by ornamental bands, embellished with carved columns and niches. The portals of the so-called Uzbek mosque in Solkhat (Stary Krym) and of the Church Surb Nshan (of the Sign) of the Surb Khach Monastery near the same town demonstrate evident similarity. Only the symbolic medallions and inscriptions indicate the religious message of each of the portals. We may ask the question of whether there was an interchange of ideas, or whether the same masters worked on both locations. Artistic taste is a decisive moment in the development of monumental art, which should be taken into consideration while trying to explain the origins of architectural forms.

With the active "mediation" of Italian models, it seems, there emerges a standard type of middle-size portals, which do not look as imposing as those of the mentioned constructions do. This is a portal with a lancet archivolt on consoles, made over the lintel. At the same time with the similarly active "mediation" of Armenian models a new portal becomes widespread - in the form of a frame, decorated with the so-called Seljuk chain. Finally, in Crimea we see the meeting and partial convergence of three different traditions regarding the design of lapidary construction inscriptions.

It may seem that in certain historical periods, for instance, in the 14th-15th centuries, the mutual integration of architectural traditions led to the creation of a single Crimean architectural style. If one looks at the details, there is a possibility to give an affirmative answer. But, if looking at architecture, we turn to concepts of composition and image, we simply have to accept once more the fact that even when sometimes similar forms and ornaments are used, the result turns out to be different. Furthermore, what is essential and most important, in almost all the cases this result reflects the national spirit and the imagery of a concrete culture. There is no doubt that a Tatar mosque cannot be confused with a Greek church. But it is more difficult, sometimes impossible, to tell the difference between a Greek, Armenian or Genoese church when it is built of the simplest type of a vaulted hall, and when liturgically significant forms have not been preserved (Church of the Twelve Apostles in Sudak). 


\section{CONCLUSION}

Preliminary results of research conducted during the last several years prove the importance of an approach to architectural constructions and phenomena involving methods of art history. It is inevitable to stop limiting ourselves to simply studying construction techniques and typology. Research will provide us with a possibility to discover the features connected with the integration of national traditions. Preserving architectural images characteristic of each ethnic group, Crimean masters worked on objects that belonged to different confessions, even though the construction technique had much in common, as well as the details and ornaments. The study of architecture on the peninsula will prove to be a success if we turn to various methods of critical analysis in connection with each monument, taking into account the broad context of the development of Medieval architecture.

\section{REFERENCES}

[1] L. Bertie-Delagard, Antiquities of the Southern Russia. Excavations of Chersoneses, Materials on the archeology of Caucasus. St. Petersburg, Imperial Archeological Commission, 12, 1893, p. 22.

[2] L. G. Khrushkova, The Byzantine architecture of the Chersonese in Crimea: History, methods and outcomes of the study", Questions of the history of world architecture, 6, 2016, pp. 9-46.

[3] L. G. Khrushkova, Christian monuments of Crimea (State of research), Vizantiiskii Vremennik (BYZANTINA XPONIKA), 63, 2004, pp. 167-194.

[4] V. V. Maiko, Christian church under the mount Kilisa-Kaia near Sudak, Materials of the scientific conference Archeology of Medieval Church, Sept. 25-29, 2017, Sevastopol, 2017, pp. 44-46.

[5] A. L. Yakobson, Medieval Crimea, Moscow - Saint-Petersburg, Nauka, 1964.

[6] O. Kh. Khalpakhchian, The stages of planning and redevelopment of Feodasia (from ancient times to the end of the 18th century), Architectural Heritage, 25, Moscow, Stroiizdat, 1976, pp. 35-49.

[7] O. Kh. Khalpakhchian, Religious buildings of Crimea, Architectural Heritage, 39, Moscow, Stroiizdat, 1992, pp. 32-45.

[8] V. P. Kirilko, Golden Horde architecture in Crimea, Mediaval Eurasia: symbiosis of towns and the steppe, Kazan, Otechestvo, 2013, pp. 8499.

[9] V. P. Kirilko, Periodisation of Construction of the so called Uzbek Mosque from Stary Krym, The Genoese Gazaria and the Golden Horde, Kazan - Simferopol - Kishivev, Stratum Plus, 2015, pp. 509558.

[10] E. D. Zilivinskaya, Architecture of the Golden Horde. Part I. Religious architecture. Kazan, Otechestvo, 2014.

[11] A. I. Komech, The Church of Decapitation of John the Baptist, Zograf, 22, 1992, pp. 28-41.

[12] V. A. Sidorenko, The study of architectural styles of the SouthEastern Crimea, Architectural-archeologilal investigations in Crimea, Kiev, Naukova Dumka, 1988, pp. 115-128.

[13] S. G. Bocharov, Fortification constructions of Kaffa (late-13th - the second half of the 15th centuries), Black Sea littoral in the Middle Age, 3, 1998, pp. 82-116.

[14] V. L. Myts, Kaffa and Theodoro in the 15 th century. Contacts and conflicts, Simferopol, Universum, 2009.

[15] M. Yu. Mogarichev, Cave churches of Tauria, Simperopol, Tauria, 1997.

[16] E. A. Aibabina, Defence constructions of Kaffa / on the matherials of archeological excavations, Architectural-archeologilal investigations in Crimea, Kiev, Naukova Dumka, 1988, pp. 67-81.
[17] V. P. Kirilko, Fortress ensemble of Funa (1423-1475), Kiev, Stilos, 2005.

[18] A. Yu. Kazaryan, E. A. Loshkarieva, The Riddles of the Church of John the Baptist in Feodosia and the problems of its new architectural-archeological study, Materials of scientific conference Archeology of Medieval Church", Sept. 25-29, 2017, Sevastopol, 2017, pp. 31-34. 